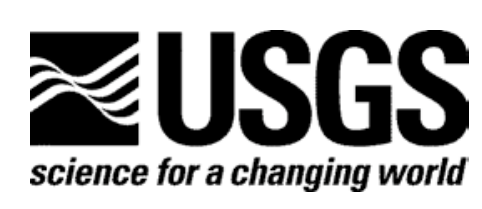

\title{
Geomorphic Map of Worcester County, Maryland, Interpreted from a LIDAR-Based, Digital Elevation Model
}

By Wayne L. Newell and Inga Clark, U.S. Geological Survey, Reston, VA 20192

Report Series 2008-1005

U.S. Department of the Interior

U.S. Geological Survey 


\section{U.S. Department of the Interior DIRK KEMPTHORNE, Secretary}

\section{U.S. Geological Survey \\ Mark D. Myers, Director}

U.S. Geological Survey, Reston, Virginia 2008

For product and ordering information:

World Wide Web: http://www.usgs.gov/pubprod

Telephone: 1-888-ASK-USGS

For more information on the USGS-the Federal source for science about the Earth, its natural and living resources, natural hazards, and the environment: World Wide Web: http://www.usgs.gov

Telephone: 1-888-ASK-USGS

Suggested citation:

Newell, Wayne L., and Clark, Inga, 2008, Geomorphic Map of Worcester County, Maryland, Interpreted from a LIDAR-Based, Digital Elevation Model, U.S. Geological Survey Open-File Report 2008-1005, 34 p.

Any use of trade, product, or firm names is for descriptive purposes only and does not imply endorsement by the U.S. Government.

Although this report is in the public domain, permission must be secured from the individual

copyright owners to reproduce any copyrighted material contained within this report. 


\section{Contents}

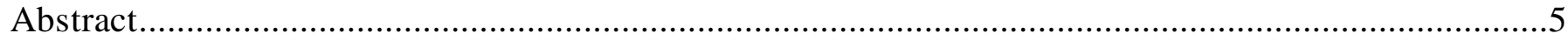

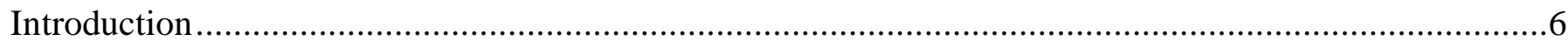

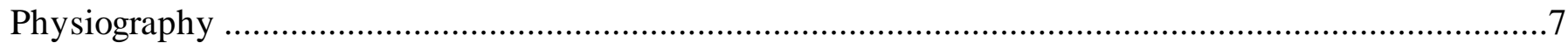

Geologic framework

The LIDAR-based DEM map of Worcester County, MD ………....................................................12

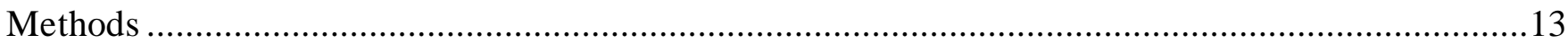

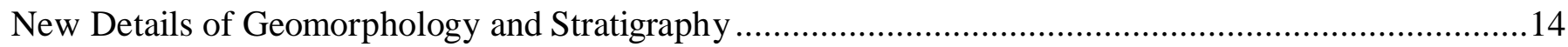

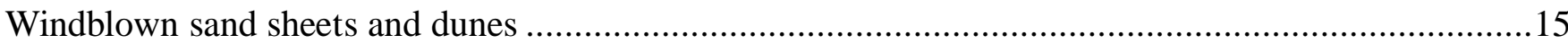

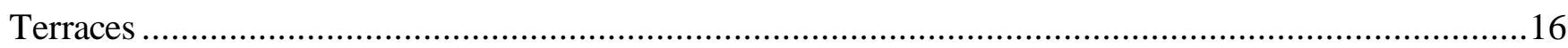

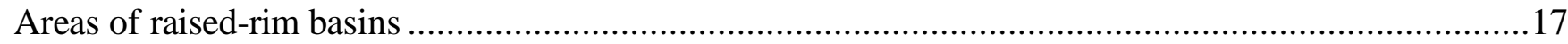

The Raised-rim basin terrains include the following newly described atributes...................................18

Details of flood plains, tidal wetlands, and

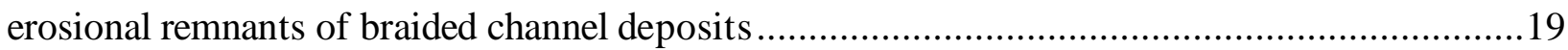

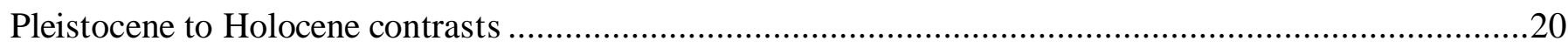

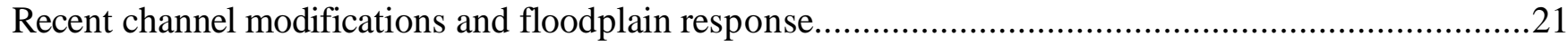

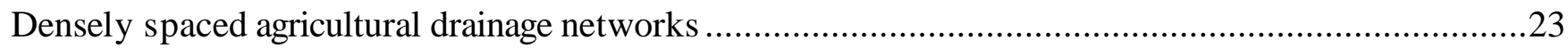

Geomorphic features on Pleistocene and Holocene Transgressive deposits in litorral/back-bay environments of the Atlantic coast portion of

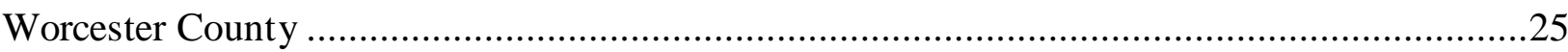

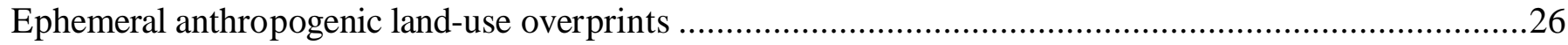

History of the landscape interpreted from sequences of cross cutting topographic

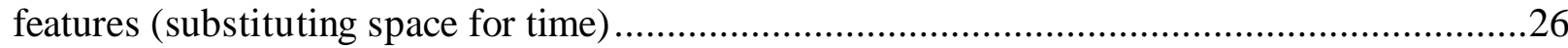

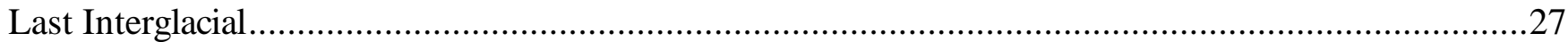

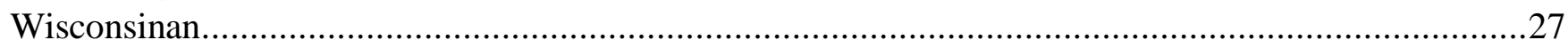

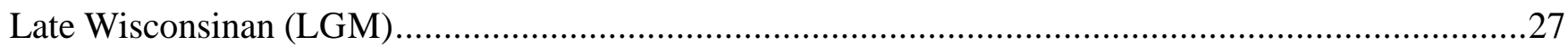

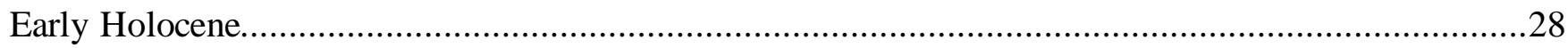

Middle Holocene.

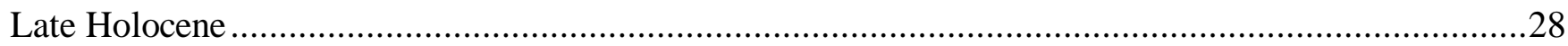

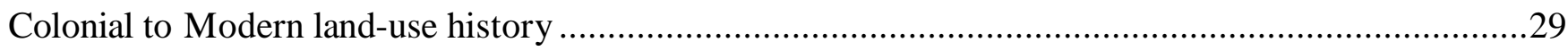

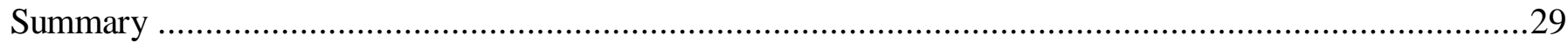

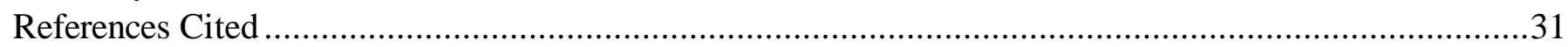




\section{Figures}

1. Location of Worcester County on the Delmarva Peninsula between the

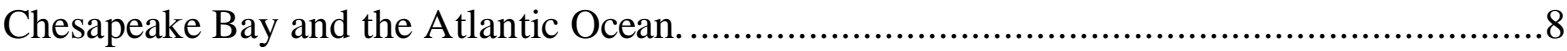

2. A complilation of Surficial Geology from Figure 2 of Bricker and others, 2003....................11

3a. Cross section of stratigraphic details of Nassawango Creek flood plain

alluvium down stream from gaging station (see Plate 2) ..........................................22

3b. Schematic diagram of geomorphology of flood plain along Nassawango

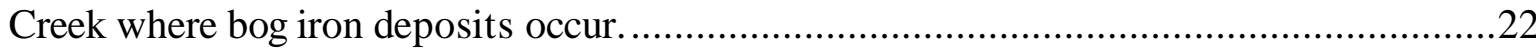

4. Ditching of the Pocomoke River watershed (from Bricker and others, 2003 ........................24

\section{Tables}

1. Depositional environments and relative ages of surficial deposits in Worchester

County from outcrop and corehole data and cross cutting relationships. 


\title{
Geomorphic Map of Worcester County, Maryland, Interpreted from a LIDAR-Based, Digital Elevation Model
}

\author{
By Wayne L. Newell and Inga Clark, U.S. Geological Survey, Reston, VA 20192
}

\begin{abstract}
A recently compiled mosaic of a LIDAR-based digital elevation model (DEM) is presented with geomorphic analysis of new macro-topographic details. The geologic framework of the surficial and near surface late Cenozoic deposits of the central uplands, Pocomoke River valley, and the Atlantic Coast includes Cenozoic to recent sediments from fluvial, estuarine, and littoral depositional environments. Extensive Pleistocene (cold climate) sandy dune fields are deposited over much of the terraced landscape. The macro details from the LIDAR image reveal 2 meter-scale resolution of details of the shapes of individual dunes, and fields of translocated sand sheets. Most terrace surfaces are overprinted with circular to elliptical rimmed basins that represent complex histories of ephemeral ponds that were formed, drained, and overprinted by younger basins. The terrains of composite ephemeral ponds and the dune fields are inter-shingled at their margins indicating contemporaneous erosion, deposition, and re-arrangement and possible internal deformation of the surficial deposits. The aggregate of these landform details and their deposits are interpreted as the products of arid, cold climate processes that were common to the mid-Atlantic region during the Last Glacial Maximum.

In the Pocomoke valley and its larger tributaries, erosional remnants of sandy flood plains with anastomosing channels indicate the dynamics of former hydrology and sediment load of the watershed that prevailed at the end of the Pleistocene. As the climate warmed and precipitation increased during the transition from late Pleistocene to Holocene, dune fields were stabilized by vegetation, and the stream discharge increased. The increased discharge and greater local relief of streams graded to lower sea levels stimulated down cutting and created the deeply incised valleys out onto the continental shelf. These incised valleys have been filling with fluvial to intertidal deposits that record the rising sea level and warmer, more humid climate in the mid-Atlantic region throughout the Holocene. Thus, the geomorphic details provided by the new LIDAR DEM actually record the response of the landscape to abrupt climate change.

Holocene trends and land-use patterns from Colonial to modern times can also be interpreted from the local macro- scale details of the landscape. Beyond the obvious utility of these data for land-use planning and assessments of resources and hazards, the new map presents new details on the impact of climate changes on a mid-latitude, outer Coastal plain landscape.
\end{abstract}




\section{Introduction}

LIDAR coverage of limited areas is becoming increasingly available as County and State Governments survey their terrain for assessment of hazards and resources. Although the basic data are part of the public domain, they are not yet routinely "processed" for common purposes. Interpretive maps are commonly prepared for specific issues such as flood prone areas or areas with slope stability risks. In 2004 we were provided new LIDAR coverage of Worcester County, MD with the particular purpose of generating a flood prone area analysis for coastal storms in a region of suspected accelerated sea level rise (Johnson, and others, 2006). Beyond the utility of the maps for this purpose, it was immediately obvious that these data present an exciting new tool for interpreting the geomorphology and surficial geology of the Delmarva Peninsula. Features that had been only dimly recognized on the available 7.5' contour maps and old air photos appeared in bold relief while the actual density of macro- scale features, ranging in extent between a few meters to 15 meters or more, changed the appearance of low slopes and estuarine terraces from apparently smooth surfaces to irregular terrain with 1-3 meters of detailed, local relief. The complexity of the surficial features and deposits suggested that an analysis of the morphological sequences of land forms could provide much new information on the geomorphic processes of the late Pleistocene and transition into a warming Holocene climate at mid-Atlantic latitudes. An earlier, recent study of sediment and nutrient cycling, and bog iron deposition in the Pocomoke River valley (Bricker, and others, 2003), provided a foundation for the surficial geology and geomorphology of Worcester County. This report presents our analysis of the late Pleistocene to Recent geologic history that can be interpreted from the geomorphic relationships of the deposits and their macro-topographic expression. This map can be used to inform further studies of the sedimentological details of the deposits that can be revealed by GPR profiling and dated with ${ }^{14} \mathrm{C}$ and OSL techniques. Locally, peat deposits are sufficiently distributed in cores to support studies of changing forest assemblages that can proxy for climate changes. This map should further encourage the acquisition of more extensive LIDAR coverage both for its land use planning utility and for its obvious relevance to expanding our understanding of landscape change as a function of climate change. 


\section{Physiography}

Worcester County, Maryland, is located on the Atlantic Coast of the Delmarva Peninsula between Delaware to the north and the Virginia counties to the south (see Index map, Figure 1). The highest uplands occur on the western and northern county margin. The uplands are sandy, low relief plains, ranging between 10 to 30 meters in elevation. Areas not under intensive cultivation support pine and oak forests that have been timbered many times since the beginning of colonial agriculture almost 400 years ago.

East of the central uplands, the Pocomoke River valley heads in a Cypress Swamp on the Delaware-Maryland line. It runs south to southwest to its confluence with Pocomoke Sound of the Chesapeake Bay in Virginia. Low terraces bound the River between sea level and 8 meters. The low terraces define previous Quaternary extents of the Pocomoke Valley estuary during serial high stands of sea level.

The eastern divide is a north-south complex of former barrier islands (now $8 \mathrm{~m}$ above sea level) that are roughly parallel to the present-day barrier island shoreline of the Atlantic Ocean. The main stem of the Pocomoke River and its flood plain are filling a deeply eroded valley that was cut at least $8 \mathrm{~m}$ to $15 \mathrm{~m}$ below present sea level during several antecedent low stands of sea level (LGM and Illinoisan). Beyond the eastern interfluve, short stream valleys drain eastward to Assawoman Bay and Chincoteague Bay and to the Atlantic. Chincoteague Bay and the Assawoman Bay are separated from the Atlantic by a chain of barrier islands that includes Assateague Island. Extensive salt marsh wetlands fringe the Chincoteague Bay and Assawoman Bay.

Wetlands of the Pocomoke River in Worcester County are tidal but of low salinity. Tidal influence extends up river beyond Snow Hill, but the water is commonly fresh in those reaches. Down river beyond Pocomoke City, the tidewater is marginally salty $(<2 \mathrm{ppt})$ and the salinity increases down the river beyond the state line. Forested wetlands are common on the flood plain of the Pocomoke and its major tributaries, the Nassawango Creek and Dividing Creek. Cypress swamps, formerly extensive on the forested wetlands, were timbered during development in the $17^{\text {th }}, 18$ th, and $19^{\text {th }}$ centuries. The flood plain of the watershed includes low relief, extensive forested wetlands, groundwater discharge, and tidal fresh water. These criteria all characterize the Pocomoke River as a classic "blackwater" river that transports minimal sediment, sustains high groundwater-fed base flow and is stained with tannin from the roots of conifers.

Pocomoke City, Snow Hill, Berlin, and Ocean City are the main urban areas of the county which is largely agricultural. 


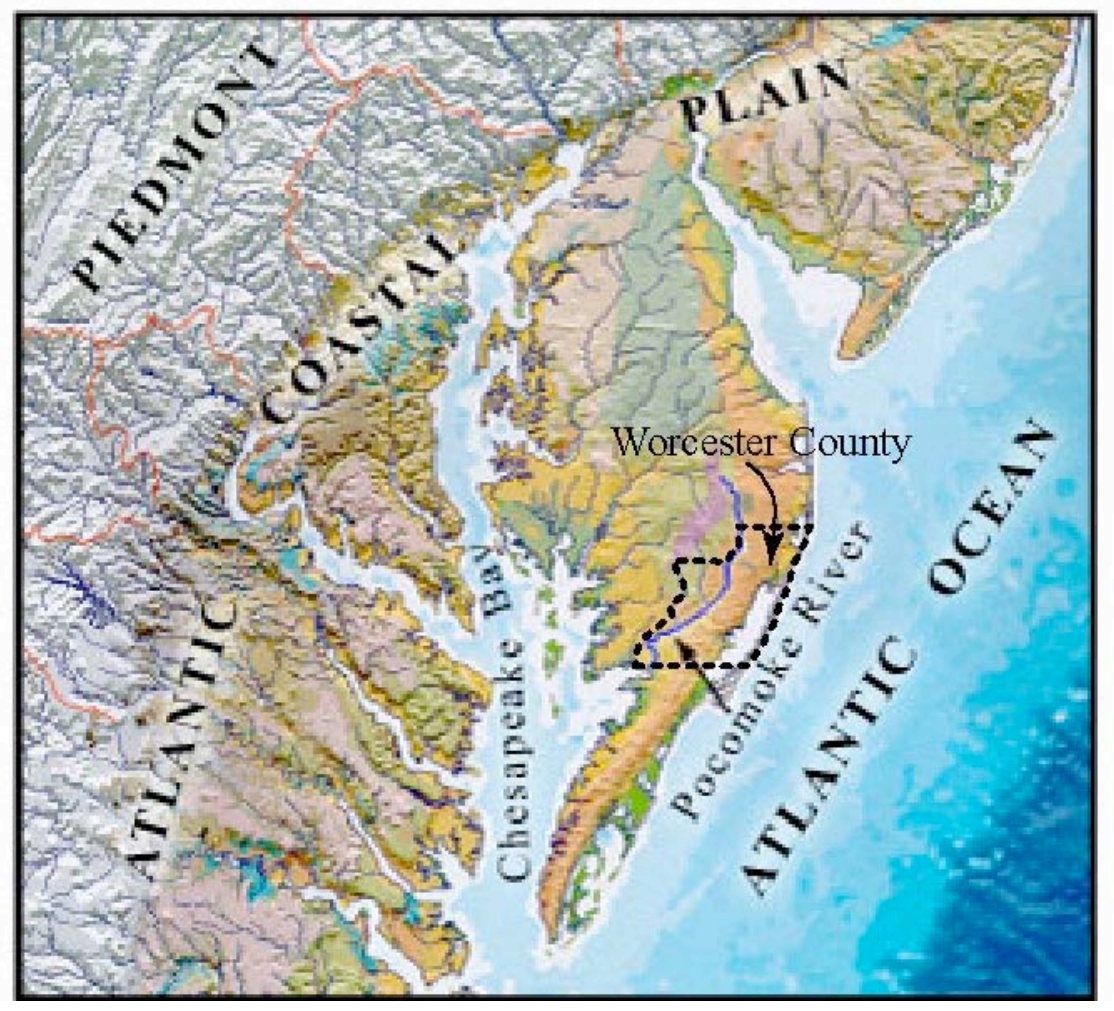

Figure 1. Location of Worcester County on the Delmarva Peninsula between the Chesapeake Bay and the Atlantic Ocean.

\section{Geologic Framework}

The geologic framework of Worcester County was described by Owens and Denny, (1978). Prior to their work, Hall, (1973), published a county soil survey. (Additional maps of Worcester County soils include Perkins and Bacon, 1924, and Demas and others, 2004). Rasmussen and Slaughter, 1955, described the water resources for the middle Delmarva counties. Rasmussen and Slaughter, (1955), originally described and named several stratigraphic units including the (Pliocene?) Beaverdam formation and the (late Pleistocene) Parsonsburg Sand. The uplands are underlain by the (MiocenePliocene) Pensauken Sand, a fluvial-deltaic deposit of quartz and chert- rich gravel that includes minor rock fragments and distinctive assemblages of labile and heavy minerals from the Appalachians. These deposits are tens of feet thick, deeply weathered and altered, and comprise the upper delta plain core of a major coastal plain delta that had its provenance to the northeast in Pennsylvania, New Jersey, and New York. Owens and Denny, $(1978,1979 b)$ considered the Pensauken to be Miocene. These gravel deposits underlie the upland surfaces and have provided most of the sediment eroded and redistributed in the younger, adjacent Pleistocene terrace deposits of the Delmarva Peninsula.

Locally, a possibly younger formation known as the Beaverdam is inset in the Pensauken gravel of the uplands, it may also occur at depth as described in water well logs and test borings of Owens and Denny, (1978). The Beaverdam is thought to be late 
Tertiary (late Pliocene) and is also reworked from the Pensauken. However, a feldspathic sand component might indicate continued input of first cycle sediments from the northeast provenance.

The sequence of Pleistocene terrace deposits includes the Omar/Accomack, Ironshire, and Kent Island/ Sinnepuxent Formations of Owens and Denny (1978). The Omar Sand is the higher of the two terrace deposits ( $~ 8$ meters) and in Worcester County includes a complex paleogeography of an offshore barrier island complex with bay muds deposited between the sandy barrier island chain on the east, and the weathered, eroded uplands of Pensauken/Beaverdam sandy gravel on the west. Currently, these deposits are thought to represent stage 7 from the Shackleton and Updike oxygen isotope curve (Shackleton, 1977). Similar terraces on the west side of the Chesapeake have been dated at 180,000 to 200,000 ybp (Mixon, and others, 1982). The modern Pocomoke valley has entrenched through the paleo-bay deposits of the Omar (During low-stand Stage 6). Backfilling during the last major global warming event, ranging between Stage 5e and Stage 5a (Wehmiller and others, 2004), left the inset terraces of the Kent Island and Sinnepuxent Formations generally below 5 meters elevation. During the last sea level low stand/ Last Glacial Maximum (LGM), Stage 2, the Pocomoke River entrenched below the deposits of the Kent Island Formation. Both sets of terraces are embayed far upstream into the upland interior of the Pensauken Formation. The fluvial to estuarine terraces have been conduits of coarse-grained sand and gravel eroded from the Pensauken Formation and deposited at the mouths of the tributaries in the Omar and Kent Island Formation terraces.

Superposed on the upland core deposits and terrace deposits is a ubiquitous blanket of wind-blown sand ranging from 1 to 15 meters thick (Denny and Owens, 1979). This deposit, known as the Parsonsburg Sand, has yielded un-calibrated ${ }^{14} \mathrm{C}$ ages ranging from 30,000 to 13,000 years before present (Sirkin and others, 1977). These ages place it well within the period from the LGM to the end of the Pleistocene. Early analyses of pollen from the peat deposits within the Parsonsburg Sand indicate that spruce and nonarboreal vegetation was prevalent during the colder climate intervals. These cold tolerant species gave way to more abundant pine and oak as climate moderated after the LGM.

Modern alluvium with swamps, salt marsh, and beach deposits were also delineated on the Worcester county map of Owens and Denny (1978). The sequencing and environment of deposition of the shallow Tertiary and Quaternary surficial deposits is shown in Table 1. The spatial distribution of the map units largely derived from earlier mapping of the Pocomoke River basin is shown on Figure 2 as compiled in Bricker and others (2003). 
Table 1. Depositional environments and relative ages of surficial deposits in Worcester County from outcrops, core holes, and cross cutting relationships

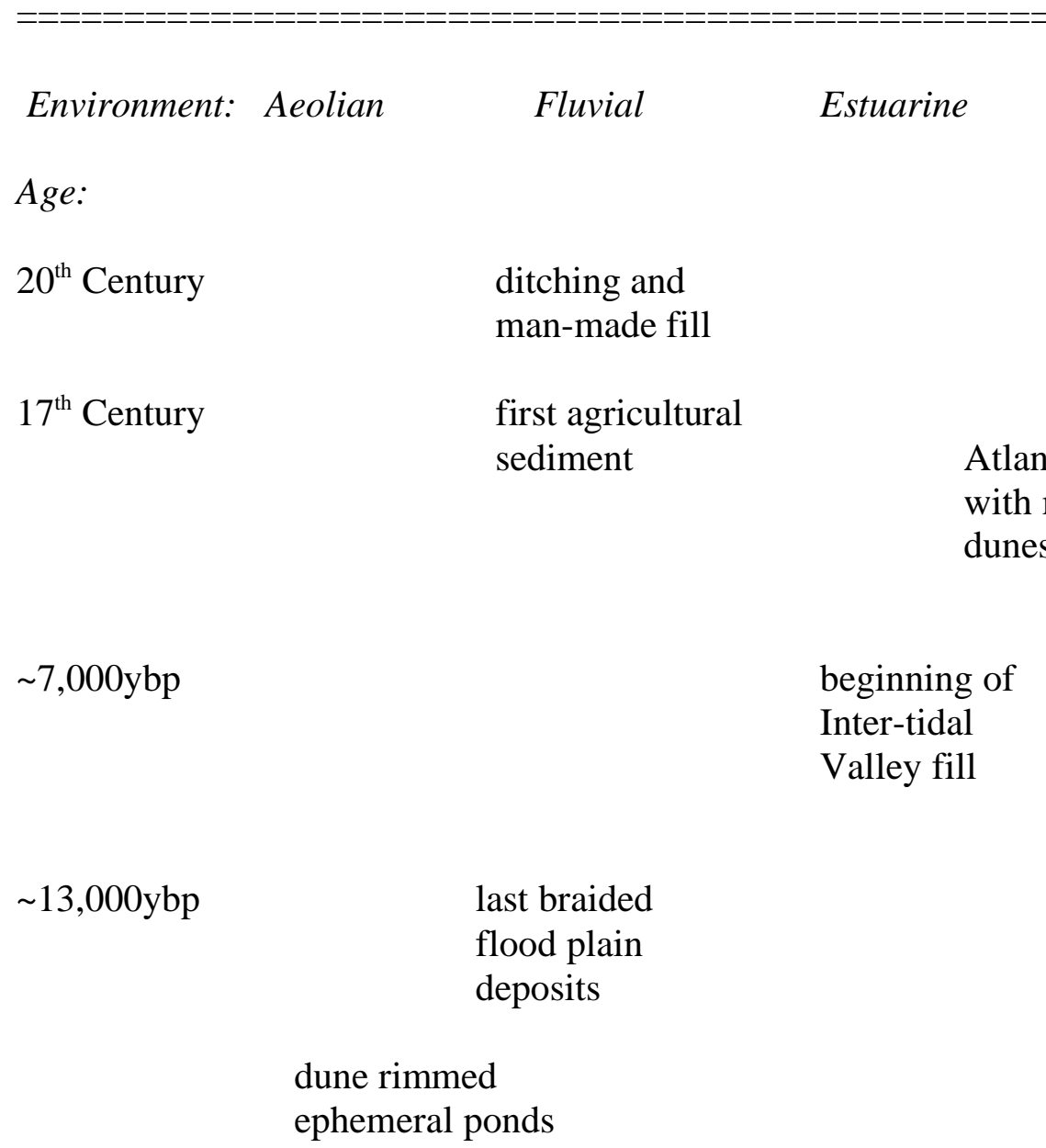

13,000ybp- Parsonsburg Sand

30,000 ybp

Late Pleistocene:

Stage 5 to Stage 3

Kent Island Fm.

Ironshire Fm.

Sinepuxent Fm.

Stage 7

Omar Fm.

Pliocene

Beaverdam Fm.

Miocene-Pliocene Pensauken Fm. 


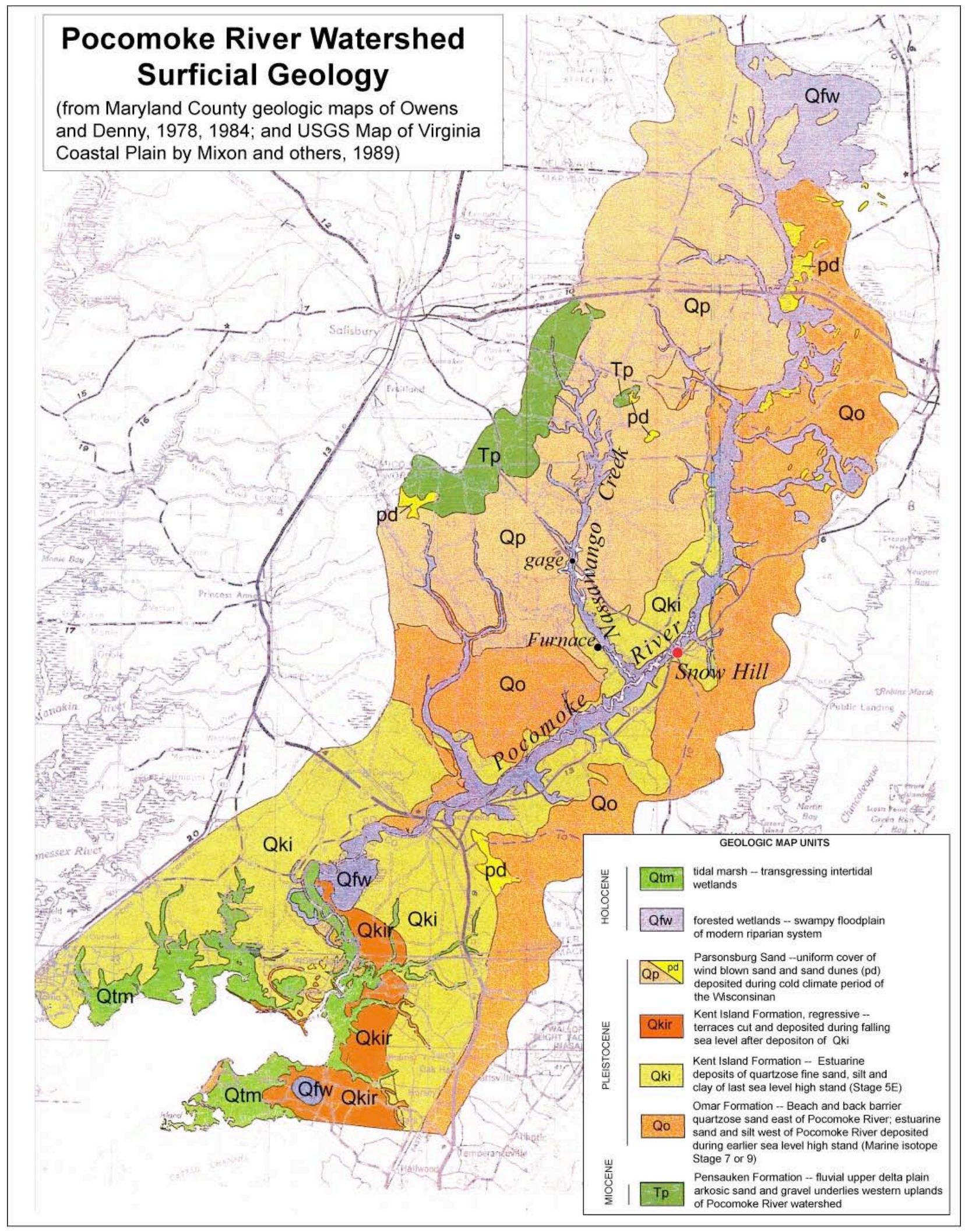

Figure 2. A compilation of Surficial Geology from Figure 2 of Bricker and others, (2003). 
One of the striking features visible on the LIDAR-based DEM map (Plate I, II) is the densely packed arrays of abundant closed, round to elliptical depressions. Early series of topographic maps with 10 foot, 5 meter, or greater contour intervals were insufficient for delineating many closely spaced terrace intervals, or details of surface roughness or other variations characteristic of the surficial deposits. For example, only the most prominent, elliptical ponds or "spungs" were delineated where they intersected a contour interval. Early aerial photographs probably taken for the USDA showed a denser packing of the so called "Carolina" or "Maryland Bays" (Rasmussen and Slaughter, 1955). Inspection on the ground of fields at winter and remnants in salt marshes, revealed the closed basins and the ridge and furrow topography of the dune fields. These have been studied effectively by C. S. Denny and Owens (1979). However, interpretation of the details of these features and their underlying deposits has been hindered by lack of data.

Rasmussen and Slaughter (1955) described the closed basin, raised rim depressions, and interpreted them as melt out kettles from ice rafted blocks during the Pleistocene, At the time of their work, the Pensauken was locally called the Columbia gravel in Delmarva and was thought to be Pleistocene outwash (McGee, 1888; Jordan, 1964). It is now known that this is not possible because the Pensauken and Beaverdam Sands are fluvial to marine littoral deposits dating from warm periods and sea level high stands (Owens and Denny, 1978, 1979b). Sirkin and others (1977) and Mixon (1985) described the arrays of "Carolina bays" as cold climate artifacts overprinted on the substrate of terrace deposits.

Prior to LIDAR imagery and new geophysical profiling techniques (Ground Penetrating Radar, GPR), little could be done to advance the description and interpretation of cross cutting relationships of the macro-scale topographic features. The superimposed topographic features now reveal an interesting history of landscape response to changing climate dynamics in the mid-Atlantic region.

\section{The LIDAR-Based DEM Map of Worcester County, Maryland}

In 2003-4 LIDAR map bases became available for parts of tidewater Maryland and a project was created to assemble the pieces of surveys into a seamless DEM and interpret it for tidal and storm driven floods in the low lying areas of the county. The map data base was processed to minimize the effect of the forest cover (first return) on the perceived topographic details. What emerged was a new view of the geomorphic details on what had been commonly shown on traditional contour maps as a low relief, featureless plain. Distinctive textures with topographic relief in the range of 0.5 to $3+$ meters can now be distinguished and interpreted.

Light Detection and Ranging (LIDAR) is a method of distance measurement using laser light. A scanning laser is mounted on an aircraft that flies across topography in a sub parallel sequence of lines. The laser emits a series of light pulses in a side-toside motion. The time required for the pulse to return to the aircraft's sensors is recorded. GPS position of the aircraft and its altitude is also recorded during the flight. LIDAR can be used to obtain ground surface elevations as well as elevations of vegetation cover and man-made structures along the flight line. Elevation data obtained by this method is very detailed and accurate. It is being used for a variety of purposes including hydrology and 
floodplain studies, shoreline mapping, urban development and natural resources management.

\section{Methods}

Worcester County LIDAR data was acquired through a joint project between the Maryland Department of Natural Resources (MDNR), USGS, and Worcester County government. Raw LIDAR data was collected by 3Di, Inc. in August 2002 and by Airborne 1 in April-June 2003 to fill in the gaps not covered by the 2002 mission. Flight operations were performed during leaf-off conditions and during low-tide cycle when possible. Raw data was referenced to UTM coordinates. The first- and last-return data was processed by the Computational Consulting Services, LLC using the proprietary software. Artifacts and features that do not reflect ground elevation were eliminated to create Bare Earth Mass Point files. Data was re-projected to State Plane Coordinate System NAVD88 with elevations in meters referenced to NAD83 datum. A gridded Digital Elevation Model (DEM) was created from the Bare Earth Mass Point Files using 1,200 meter by 1,800 meter tiles. Cell size for the DEM grid was 2 by 2 meters. One meter resolution imagery, resembling a digital ortho-photograph, was also generated by the Computational Consulting Services, LLC using the LIDAR return intensity data. Both the Bare Earth Mass Point files and the gridded DEEM files, were independently checked for consistency and accuracy by NXL Construction Services and by Dewberry LLC. The testing determined that final products meet the FEMA and MD DNR requirements for vertical accuracy. Horizontal coordinates for each surveyed point meet the National Standard for Spatial Data Accuracy (NSSDA).

LIDAR data was delivered to the USGS in the form of GBare Earth Mass Point files and as Gridded DEM files. ESRI, Arc GIS software was utilized for the project. Gridded DEM files in Arc/Info interchange file format (*.e00) were used to create a DEM map of Worcester County. Original files were imported into an ESRI Grid format and their projection was defined to the Maryland State Plane, NAD83 projection. Separate tiles were then merged together to form 15 rows each consisting of 36 to 84 tiles. Elevation ( $\mathrm{z}$ ) values of the LIDAR data had to be converted from meters to centimeters due to the file size limits. Using the Arc/Info Grid utility, meter-unit floating point grids representing each of the 15 rows were converted into a cm-unit inter grids. During the conversion from a floating point grid to an integer grid, Arc/Info Grid truncates decimal places instead of rounding to the nearest number. To ensure better accuracy of the integer grid a simple Arc/Info routine was created:

1. The original floating point and the resulting integer grids were compared

2. If the difference between the z-values for each cell was greater than $0.5 \mathrm{~cm}$ then this cell was assigned an elevation value of one centimeter higher (or lower in case of negative z-values) otherwise it was left the same.

Fifteen rows were merged again to create a composite LIDAR-based DEM; map of Worcester County. Upon checking the map for discrepancies in elevations between neighboring tiles/rows, a 15 to $>60 \mathrm{~cm}$ difference was noted (Johnson and others, 2006) The precision of LIDAR data is generally around $15 \mathrm{~cm}$, therefore some areas in question 
were within the acceptable range. To smooth out bigger elevation differences between the adjacent tiles, the whole DEM grid was filtered using a $7 \mathrm{X} 7$ cell-size median filter.

The resulting county-wide DEM map is a grey-scale map. We chose the color ranges for the elevation values that reflect significant changes in topographic elements including terraces, scarps, and other linear features (Plate I, II). The lowest elevation in the area is $-31 \mathrm{~cm}$ and the highest is $3507 \mathrm{~cm}$. The elevation change was divided into 32 intervals. First three class breaks were chosen to correspond to the elevations of Mean Sea Level (MSL), Mean High Water (MHW) and spring tides characteristic for this area. Elevations for these water levels were based on the tidal datum and benchmark information from the Ocean City tide gages (Fishing Pier, Isle of Wight, and Ocean City Inlet). Breaks in elevation classes were chosen to be $50 \mathrm{~cm}$ and $100 \mathrm{~cm}$, depending on the density of data in a particular elevation range. To improve the visual representation of the area topography on the map, we created a shaded relief map. A hill shade grid of the area was generated from the elevation values using the ArcView Spatial Analyst extension. Hill shading provides a three-dimensional view of an area in two-dimensions by calculating illumination of each cell of an image based on the specified sun azimuth

and altitude. A vertical exaggeration factor could also be applied to give more depth to a map surface. Color-coded DEM map of the Worcester County was overlain on top of the hill shade grid thus producing a 3D map of the area.

Additional layers of roads and railroads were acquired from the MD DNR and combined with the County DEM. Spatial reference of the shape files was changed when necessary to the State Plane NAD83 projection.

The resulting map was exported to an Adobe Illustrator 11.0 file for further analysis of the surficial features. Since some of the features are more pronounced on the grey-scale DEM map, it was also exported as an additional layer to the Illustrator file. Through the visual analysis of the map and comparison of the grey-scale and color coded versions of the DEM map, we delineated outlines of rimmed, closed depressions ("Maryland or Carolina bays"), dune fields, barrier ridges, river meanders, flood plain details, and man-made structures in Worcester County. A legend was created that shows elevation classes and the symbology for the topographic features that can be delineated on the new map.

\section{New Details of Geomorphology and Stratigraphic Relationships Interpreted from the LIDAR Map}

The Delmarva Peninsula is a region of extremely low relief. The highest elevations in Worcester County, MD barely exceed 25 meters. At least $60 \%$ of the county area is less than 10 meters above sea level and as much as $30 \%$ of the land area is below 3 meters above sea level. Common topographic maps from the mid-20 ${ }^{\text {th }}$ century have contour intervals of 10 or 20 feet. Even 5 foot contours from the most recent 7.5 minute quadrangle maps reveal only the most prominent topographic features including abrupt marine terrace scarps, sparse, large circular to elliptical flat areas with raised rims, and irregular large dunes.

Aerial photographs and ortho-photo quadrangle maps, some with metric intervals of 1-2 meters, reveal a more extensive continuum of macro- topographic relief features that can be distinguished in the field. However, site specific plane table and alidade 
surveys of small areas at scales ranging from 1:10 through 1:100 would have to be made to provide the resolution now available on a DEM created with LIDAR altimetry.

Because the Worcester County LIDAR derived DEM presents elevations in colorcoded intervals, it is important to recognize that the macro-topographic patterns are distinguishable first on the gray scale of the shaded relief map base. The gray scale is enhanced in part by the color gradient of several topographic intervals that particularly accentuate marine terrace scarps, some rimmed, closed basins, and the steep, lee slopes of dunes.

Adding the color gradients of finely spaced contour intervals (ranging from $25 \mathrm{~cm}$ to $100 \mathrm{~cm}$ ) particularly enhances the common altitudes at the toes of estuarine scarps where sea level had been the common datum. Other macro-topographic features occur at almost any altitude and present the appearance of surficial deposits that have been draped over the pre-existing topography. Fine details are also visible in the lowest terrain of flood plains now being inundated by rising sea level. The effects of coastal flooding and the dynamic inter-tidal zone can be defined (Johnson and others, 2006). Even the subtleties of channel straightening and vast networks of drainage ditches can be documented more effectively than previously possible from earlier topographic map bases. Ditch systems in former fields can still be distinguished in areas now covered with forest.

\section{Wind Blown Sand Sheets and Dunes}

On the Worcester County Geologic map, Owens and Denny (1978) mapped the Parsonsburg Sand for the most part where distinctive antecedent topography and surficial map units were obscured. The new map reveals the domain of the Parsonsburg as shingled sand sheets, imbricated to the northwest. The leading edge of each sand sheet is a composite pattern of curvilinear spurs and re-entrants draped over former topography or underlying sand sheets. The leading edges of these slopes are avalanche faces with relief commonly of 2-3 meters. Although distinctive "bright" edges of the avalanche faces are common, the dune field forms occur across the entire range of topographic relief and indicate a prolonged history of mobile sediment moving across the land from northwest to southeast. Thicknesses as described by Denny and others, (1978) range from less than a meter to several meters and the aggregate of age dates from underlying organic deposits range from 30, 000 years to 13, 000 years before present (uncallibrated, Sirkin and others, 1977).

The constant asymmetry of dune orientation and the quasi-parallel northeastsouthwest leading edge morphologies (avalanche faces) indicate a persistent northwest source for the wind from the beginning to end of deposition of the Parsonsburg Sand. French and others $(2003,2005,2007)$ maintain that the constant wind direction in the mid-Atlantic region is best interpreted as strong katabatic winds off the continental ice sheet during the Wisconsinan. The Laurentide ice sheet had advanced to the latitude of Long Island, NY, and across northern New Jersey and Pennsylvania, within $200 \mathrm{~km}$ of Worcester County, MD during the Last Glacial Maximum which encompassed the interval $24 / 21{ }^{14} \mathrm{C}$ ka BP (Dyke and others, 2002). 


\section{Terraces}

The upland area in the northwest corner of Worcester County is the topographic divide of the Delmarva Peninsula; the uplands are underlain by Pensauken and Beaverdam Formations but these deposits are not visible at the surface because of uniformly thick blankets of Parsonsburg dune sand. Eolian deposits are particularly thick at the headwaters of the Nassawango and Dividing Creek watersheds.

Lower altitude terrace slopes on the west side of the Pocomoke flood plain include terraces of the Omar/Accomack Formations and inset terrace deposits of the Kent Island Formation (Owens and Denny, 1978, Mixon, 1985). On the west side of the Pocomoke valley, the terrace remnants are the back-bay deposits and estuary deposits in the proto-valleys of Nassawango and Dividing Creeks. On the east side of the Pocomoke valley, the high terrain is a sequence of Barrier islands that formed the littoral deposits of the Omar/Accomack Formations (Stage 7, generally below 10 meters). The Sands are constructional land forms that include sand and gravel eroded from the Pensauken and Beaverdam Formations underlying the adjacent uplands. The Pocomoke valley is constrained by the barrier islands and the earlier uplands and it is eroded into the former back-bay deposits. The valley was eroded from a level datum and has almost no gradient. The shore face preserves scarps of coastal erosion and coastal -littoral deposits of the later Ironshire and Sinepuxent Formations (Owens and Denny, 1979), and sea level rise events within Stage 5 (5e through 5a).

Stage 5e to Stage 3 estuarine terraces of the Kent Island Formation (Owens and Denny, 1979) in the Pocomoke valley are largely confined to areas below 8 meters. Terraces on the eastern uplands (interfluve between the Pocomoke River and the Atlantic) appear to be former troughs or inlets between old barrier islands. Equivalent Atlantic shore-facing barrier island deposits occur along the bluffs of the mainland at similar elevations.

A limited set of low terraces (less than 3 meters) are eroded at the mouths of the Nassawango and Dividing Creeks and down valley to the southwest corner of Worcester County.

The younger terraces are largely cut and fill with recycled sediment. The youngest, lower terrace remnants present as surfaces with concentric to braided channel traces. Closed, rimmed elliptical basins do not occur on these deposits. The older, higher terraces are largely constructional surfaces on deposits winnowed from the Delmarva core topography. Most of the terrace margins are almost totally obscured with windblown sand of the Parsonsburg Sand draped across the topography.

Although some terrace scarps are locally abrupt, as on southwest side of Nassawango Creek, and margins of the Pocomoke, the margins with upland terrain are indistinct because they have been degraded by weathering and erosion, and have been overprinted by thick deposits of colluvium and the Parsonsburg Sand. 


\section{Areas of Raised-Rim Basins}

Scattered, flat-floored, rimmed basins, some exceeding a kilometer in diameter, have been observed across the Delmarva Peninsula even on the low resolution of the first topographic maps of mid-20 ${ }^{\text {th }}$ Century. Rassmussen and Slaughter (1955) first noted them on early agricultural air photos as abundant and pervasively developed on all the different terrace elevations. They were noted to be similar to arrays of Carolina bays further south on the outer coastal plain, and they were called "whale wallows" and "Maryland bays"; these names are still not in common use. Among several unsupported interpretations (Rasmussen and Slaughter 1955) was the possibility that the bays had been the melt-out sites of ancient ice bergs flushed down with the outwash from the north. This is not possible considering the warm climate and higher sea levels that prevailed during the emplacement of the sequences of marine-estuarine terraces. The arrays of densely packed basins are all of similar scale super-imposed on all the upland and terrace surfaces except for the very youngest $(<3 \mathrm{~m}$ elevation) terrace remnants. The morphology of the basins and their internal structure are not part of the internal depositional sequence of each terrace.

The new LIDAR topography shows that there are more than just a few large single "Carolina Bays" randomly distributed. Rather a texture of closely spaced, overlapping basins of many sizes has developed over entire terrace surfaces. All altitudes of terraces are covered except for the youngest, lowest $(<3 \mathrm{~m})$ terrace remnants. They occur extensively on the terrace surfaces of the Omar and the Kent Island Formations. Locally, basin rims appear above low marsh indicating the last vestiges of basins on terraces now being submerged along the Atlantic facing wetlands (Chincoteague Bay) and the bay facing wetlands of the nearby Pocomoke Sound.

Individual basins are circular to elliptical. The long axes of elliptical basins are oriented northwest-southeast, parallel with the prevailing wind direction during the deposition of the Parsonsburg Sand (late Pleistocene). Most basins are flat-floored with a subtle 1-2 meter rim that may be discontinuous. The basin floors are commonly silty, fine sand; the rims are slightly coarser sand and more porous. Dense arrays of basins reveal a fractal quality with dense packing of small basins in spaces between large ones.

The map patterns of densely packed basins show that the rims of older ones may be discontinuous. Younger basins locally intersect and overprint one or more older basins. Morphologic details of basin floors are of insufficient resolution to delineate the presence or absence of patterned ground that would indicate surfaces underlain by permafrost (French, 2007). Although the densely packed, rimmed basins resemble "thaw ponds" from permafrost terrains in the Arctic, The analogy cannot be assumed without appropriate petrographic evidence of permafrost deformation in these features.

Locally, the leading edges of the Parsonsburg sand dunes are over-printed on rimmed basin complexes on the Omar and Kent Island Formation terrace surfaces. Other areas of rimmed basin complexes on terrace surfaces are formed in low, deflated areas of dune field complexes.

The cross-cutting relationships of the basin rims indicate that the basins were ephemeral, possibly forming and degrading during short periods of time, for example, on a decadal or even seasonal scale. Remnant forms of older basins are overprinted by rims of younger basins; two, three, or more generations are visible. These interactive, pockmarked terranes are remarkably similar analogs to permafrost thaw ponds on the outer 
coastal plain deltas of arctic Canada and Alaska (Carson and Hussey 1962; Murton, 1996, 2001; French, 2007). The cross- cutting relationships also indicate that the arrays of basins were contemporaneous with the dynamics of the Parsonsburg sand dune fields, active during the LGM. Nearby, at similar latitudes on the New Jersey coastal plain, evidence has been accumulating for LGM dune fields and frozen ground features, including frost cracks, patterned ground, deformed and homogenized sediments in the surficial deposits (French and others., 2007). Geophysical profiling, trenching, petrographic analysis and dating of internal macro-stratigraphy are required to interpret the processes and local micro-climate that prevailed during the formation and partial destruction of these enigmatic features (French and others, 2007, Newell and others, 2000, Newell and Wyckoff, 1989). Basic evidence does not yet support the presence of an extensive permafrost environment that could have produced sequences of "thaw ponds" during permafrost degradation. Until further evidence is developed, the superimposed arrays of closed basins must be described as ephemeral ponds in an otherwise arid dune field environment. If permafrost was not a viable substrate for formation and degradation of the ephemeral ponds, then, possibly, the bay bottom mud underlying most of the terraces was sufficient to support perched water table ponds even in an arid environment. Most likely, seasonal frost and thaw were important, chronic factors to the development of the fields of ponds.

The raised-rim basin terrains include the following newly described attributes derived from the recent LIDAR image

1. Occur on Pleistocene terraces and are cored by silt-clay bay bottom substrate; basins have raised sandy rims of up to 1 meter in elevation above floor of the basins. Sands are well sorted, medium to medium fine; basins are enriched in silt/clay in basal substrate.

2. Are closely packed and randomly present many different sizes.

3. Edges are overlapping, establishing a sequence of basins that have formed, that have degraded, and that have been overprinted by features from later events.

4. Some are elliptical and sub-parallel; others are round or irregularly shaped.

(Perhaps, there may be polygenetic origins?)

5. Size, close packing, cross cutting relationships indicate that basin and rim formation unfolded as a series of cycles

6. Rimmed basins are overprinted by leading edges of sand sheets indicating that some are synchronous with wind driven processes yet others pre-date some depositional sequences of the dune fields. Not all elliptical ponds present the same orientation. In fact, randomly spaced, irregular or circular ephemeral ponds suggest that constant wind vectors and velocities were not common everywhere.

7. Rimmed basins occur on all surfaces except the very low flood plain terraces $(<3 \mathrm{~m})$ and the modern flood plain. 


\section{Details of Flood Plains, Tidal Wetlands, and Erosional Remnants of Braided Channel Deposits}

The LIDAR imagery reveals morphologic details, previously not described, from the flood plain/tidal wetlands interface in the bottoms of the Pocomoke River valley and its larger tributaries, the Nassawango Creek, and Dividing Creek.

The common channel morphology of coastal plain streams and rivers with sandy bed loads derived from sand dominated watersheds is a down valley sequence of braided channel reaches, each separated by an entrenched, meandering reach (Newell and others, 2005). Superimposed on this pattern are forested wetlands and ephemeral beaver ponds and other impediments to flow including blow downs (fallen trees) and slope deposits from local slope failures. This pattern is particularly well developed in Dividing Creek but is also distributed in the upper reaches of Nassawango Creek and the supra-tidal reaches of Pocomoke River headwaters.

The systematic function of the alternating fluvial environments is to move aliquots of sediment sporadically down the valley. The fluvial system frequently adjusts storm event by storm event to maintain equilibrium between sediment load, discharge, and gradient. Adjustments to sediment load, discharge, and gradient are accomplished by the confluence of braided channels flowing from the distal (downstream) end of an aggraded, sandy reach of flood plain. The gathered discharge at the point of confluence is sufficient to erode and entrain flood plain sediments, creating a knick point and the beginning of a single meandering channel. The meandering channel entrenches and advances the knickpoint upstream (head ward) until the sediment excavated from the entrenched meander reach exceeds the stream's power to carry it. The slug of sediment excavated from the meandering channel is deposited as an alluvial fan below the mouth of the meandering reach. The channel flows across the aggraded surface of the alluvial fan on the flood plain and bifurcates into anastomosing smaller channels that distribute sediment across the surface of the fan. Downstream, below the zone of aggradation, the anastomosing, distributary channels converge, focusing the entire discharge on another nick point, and the motif of excavation and deposition repeats somewhat rhythmically down the valley.

Internal details of the aggraded flood plain deposits, as revealed in entrenched exposures, show vertical sequences of coarse, sandy deposits inter-bedded with silty, over-bank deposits and in situ flood plain soils. Such distinctive vertical sequences of coastal plain fluvial processes are commonly encountered at depth in cores of small scale estuary fill deposits and they record the geomorphic processes at work during the early Holocene before sea level rise and inundation filled the valleys with estuary mud.

At present, rising sea level has inundated the Pocomoke River about 2 kilometers upstream from Snow Hill. It has also extended upstream a few kilometers into Dividing Creek and Nassawango Creek. In the upper reaches tidal flow is barely, if at all, salty. The Pocomoke River and its tributaries are base flow, groundwater driven, classic blackwater streams and the tidal flux is essentially the oscillation of a hydrographic peak in the fresh water discharge. Dopler velocity profiles in several tidal reaches of the Pocomoke River downstream in Virginia (Bricker, unpublished data) indicate that the flood tide and 
ebb tide velocity near the bottom of channels is not sufficient to mobilize even finegrained sediment.

Limited coring in the lower reaches of the Pocomoke (in Virginia) and other similar mid-Chesapeake tributaries suggests that the meander patterns of these rivers are generally static. Meander patterns appear to have been maintained in situ since at least the mid-Holocene. As sea level has risen, tidal wetlands have accumulated in back swamp areas behind levees along the channel. Much of the sediment stored in the back swamp areas is organic rich and extremely fine-grained. The meander amplitude and wave length of the lower tidal reach of the Pocomoke is essentially in equilibrium with the ebb and flood tide flux in the channel. Outer meander circumferences are essentially non-eroding and point bars are essentially non-accreting. Vegetation on the levees helps trap sediment and the levees accrete vertically at rates more or less synchronous with rising sea level.

This static, meandering environment is under-fit within the footprint of wider, low gradient flood plains. The valley walls that bound the flood plain are abrupt and locally cut into sand dunes that were blown out of the antecedent flood plain during the late Pleistocene. Downstream from Snow Hill, subtle terrace remnants, less than 1 meter in elevation, occur on the flood plain adjacent to abrupt valley walls. The terraces reveal subtle, short, nested channel ways. Similar terrace remnants occur down the valley below Pocomoke City to the Virginia line and in the lower reaches of Dividing Creek. We interpret these terraces as vestigial remnants of the late Pleistocene flood plain when the Pocomoke valley was awash with a sandy bed load from the highly mobile Parsonsburg dune fields. The sandy bed load overwhelmed the fluvial system of alternating braided reaches and entrenched meandering reaches so that the entire main trunk of the river and its tributaries were a continuum of braided channel reaches.

\section{PLEISTOCENE TO HOLOCENE CONTRASTS}

Downstream from Snow Hill, in the lower reaches of the Dividing Creek, and on lower reaches of the Pocomoke River near Beverly Plantation below Pocomoke City are eroded remnants of subtle terraces as low as 25 to $50 \mathrm{~cm}$ above sea level. The terrace surfaces are engraved with meander scrolls that suggest braided stream morphology and a period of aggradation that is inconsistent with modern fluvial sedimentation dynamics. The depositional environment appropriate for these terrace remnants is also inconsistent with modern tidal flooding dynamics in a rising sea level environment. These terraces cannot be modern fluvial or tidal artifacts because the flood plain has only a minimal gradient and the river does not presently have the power to erode and move large volumes of sediment as represented by these terrace remnants.

The remnants are inset against cuspate, steep banks on the southeast side of the valley. The cuspate valley margins truncate the last of the wind blown sand that was blown out of the braided flood plain valley. The low terraces of braided channel deposits are best explained as remnants of the flood plain that was extant during the period of active sand sheet and dune migration that deposited the Parsonsburg Sand. The wind blown sand choked the previously eroded river valley and established a long, continuous, braided channel. The Pocomoke River system, possibly during arid conditions, did not 
have sufficient discharge to clear it out. The braided channel aggraded to an equilibrium profile and the channel became the source of sand for the dune fields blowing from the valley bottom up slope to the southeast. The shaded relief DEM and color-coded topographic image indicates that the dunes east of the Pocomoke valley are draped like festoons across the down-wind topography. If this analysis is correct, the braided channel deposit remnants should date from the end of the Pleistocene cold period, and the entire sequence should hold evidence for climate change at the end of the Pleistocene, $\sim 12 \mathrm{ka}$. These deposits record the change in climate from a cold, dry landscape to a wetter, warmer landscape.

At the end of the Pleistocene, the unlimited supply of wind blown sand traveling across Delmarva Peninsula was stabilized. Lacking the continuous supply of wind blown sand from the Chesapeake Bay terraces and local exposed floodplains, the braided channel dynamics of the Pocomoke River flood plain and its main tributaries changed. The transition to a warmer, wetter climate contributed higher discharge, resulting in a deep incision of the Pocomoke valley. The valley gradient was re-established to a new, lower base level before rise of sea level initiated in the Chesapeake Bay at about $7.5 \mathrm{ka}$ (Vogt and others, 2000). Only a small remainder of the braided terraces has been preserved. These last remnants will be flooded, possibly within the present century. The incised channel has been back-filled during the Holocene with fluvial and estuarine deposits during rising sea level. As transgression has advanced, the sub-aerial flood plain sequences of braided and entrenched meander deposits have been buried beneath tidal cycle deposits of the pro-grading estuary. Sea level rise is filling the entrenched valley(s) with a graded sequence of fluvial to estuarine deposits. Oldest dates near the mouth of the Pocomoke in Virginia are in the range of 7,000 ybp (Bricker and others, unpublished data, 2001-2002).

\section{Recent Channel Modifications and Flood Plain Response}

During the mid-twentieth century, changing agricultural practices mandated severe drainage modifications to the entire watershed. All the low elevation, low relief, poorly drained, flat fields on the old estuary terraces (underlain by the Omar, Sinepuxent, and Kent Island Formations) were extensively trenched to speed drying of the land for large scale cultivation. Increasing the rate of runoff also required straightening the channel ways of the Pocomoke and its major tributaries. The net effect was a change in the geometry and function of macro-topographic features of the forested wetland flood plains. Some of these features are visible on the LIDAR image (Plate 1 and 2). Figure 4, from Bricker and others (2003), shows the increased density of drainage ditches; at least 1100 miles of open channels have been added to the drainage of the Pocomoke system.

Before ditching of the forested wetlands floodplain, water and sediment moved very slowly through the fluvial /system. Exposures of the flood plain sediments Figure 3, $\mathrm{a}$ and b, (Bricker and others, 2003) show as much as 1 meter of fine-grained fluvial sand covering very large, cut cypress stumps that are artifacts of land clearing probably during the $18^{\text {th }}$ century. The sediment covering the stumps is legacy sediment from the first major clearing of the land.

After ditching and channel straightening, the berms of excavated sediment along straightened reaches now function as man-made levees. Natural meandering reaches of the river have become back swamps. Remnants of earlier meander bends and alternative 
flood stage channels have become sloughs. Gaps in man-made levees now function as crevasse splays with fans of new sediment graded onto the sloughs and back swamps. Entrained sediment is still being deposited within the fluvial system and almost none of it escapes to the tidal reaches of the river.

Legacy sediment originating with colonial land clearing and continuing to present day is generally 1 meter thick. As shown on Figure 3 in the Nassawango Creek floodplain (Plates 1 and 2; see also: Bricker and others, 2003), the flood plain is covered by $\sim 0.5$ to $1+$ meters of medium to medium fine sand deposited over cut cypress stumps and burned stumps that mark the clearing. This sediment is eroded and reworked from the wind blown deposits on the uplands previously transported during the late Pleistocene.

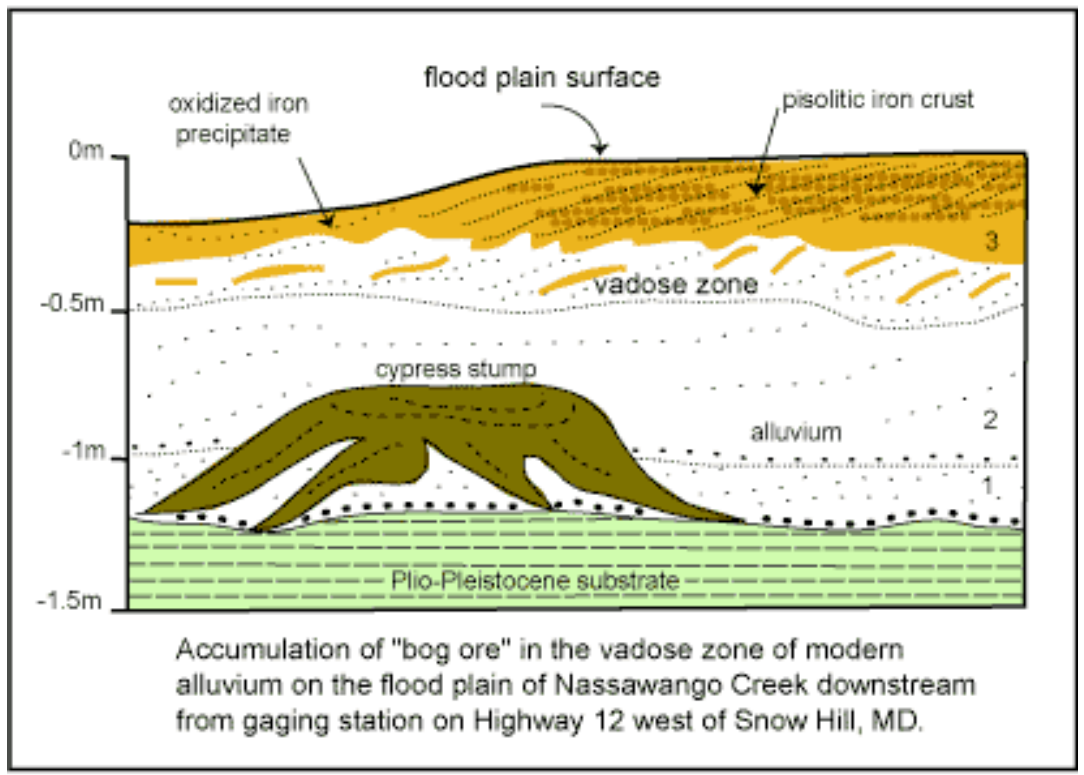

Figure 3a. Cross section of stratigraphic details of Nassawango Creek flood plain alluvium down stream from gaging station (see Plate 2). 


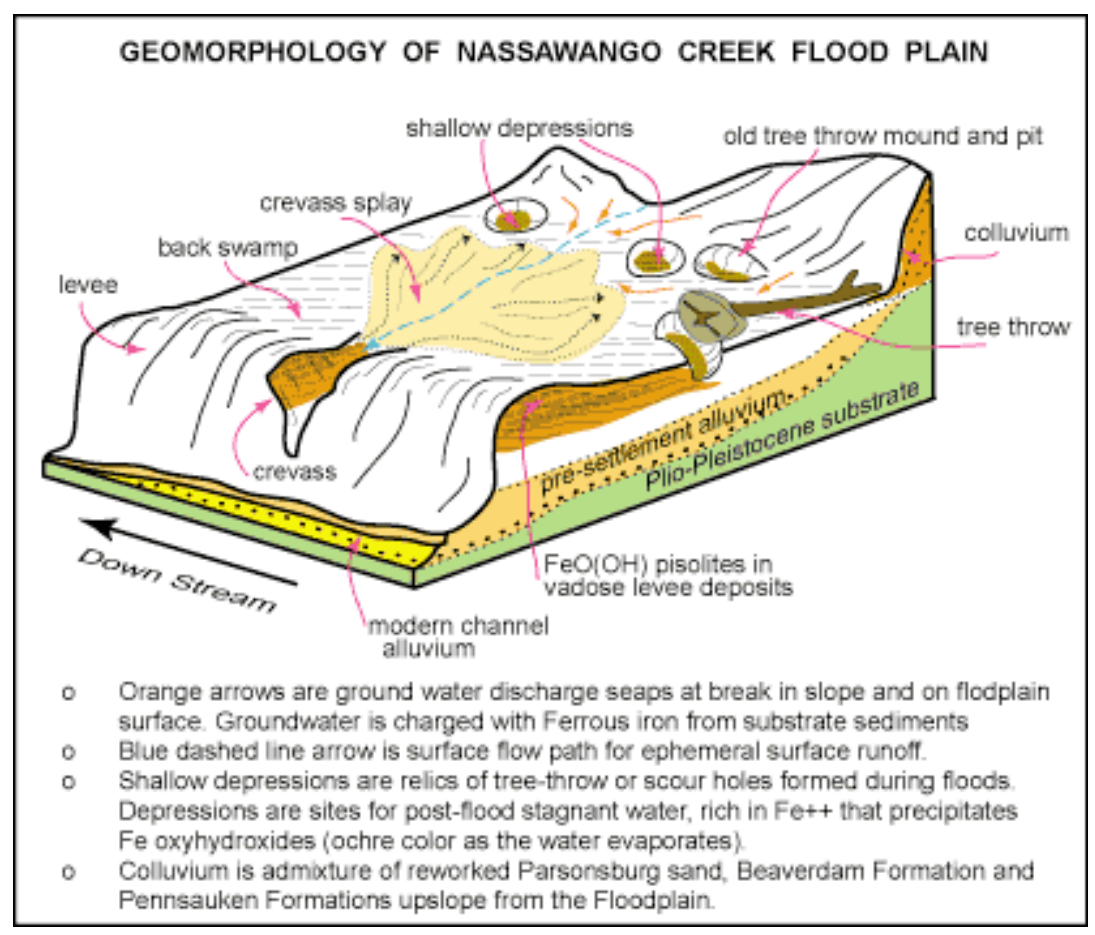

Figure 3b. Schematic diagram of geomorphology of flood plain along Nassawango Creek where bog iron deposits occur.

\section{Densely Spaced Agricultural Drainage Networks}

Nassawango Creek, Dividing Creek, and Pocomoke River valley are marked with levees and back swamps modified by linear drainage ditches that cut off the meandering main channel in an attempt to speed drainage and make fields of the watersheds more tillable. The topographic maps show extensive networks of agricultural drainage ditches. More than 1100 extra miles have been added to the watershed system. (Figure 4). The LIDAR image reveals even more densely spaced ditches and abandoned ditch networks on various terrace surfaces that are no longer cultivated and have reverted back to forests (both plantation and volunteer.)

Preservation of the ditch networks as viable parts of the fluvial system requires periodic maintenance. Initially, ditches are about 2 meters deep with steep narrow banks. Following initial digging or re-digging, the discharge in each ditch tends to re-establish equilibrium profiles with braided and meandering channel reaches widening the flood plain within each ditch; ditch banks may locally retreat and establish lower slope angles. During late summer drought, the discharge is minimal and the flood plains in the ditches are covered with vegetation that limits the mobility of the sediment during later higher discharge events. As the ditch chokes with sediment and vegetation over several growing seasons, new ditching is necessary to re-establish the function of the extant ditch network. The end effect is that brush and vegetation is cleared and sediment entrained in the fluvial system is excavated from the ditch and returned back to the fields. Very little sediment escapes to be transported beyond the head of tidewater which is upstream, north of Snow Hill. 


\section{Pocomoke River Watershed Man-made Ditches}

(derived from an unpublished map by W.L. Newell
and P. Chirico)

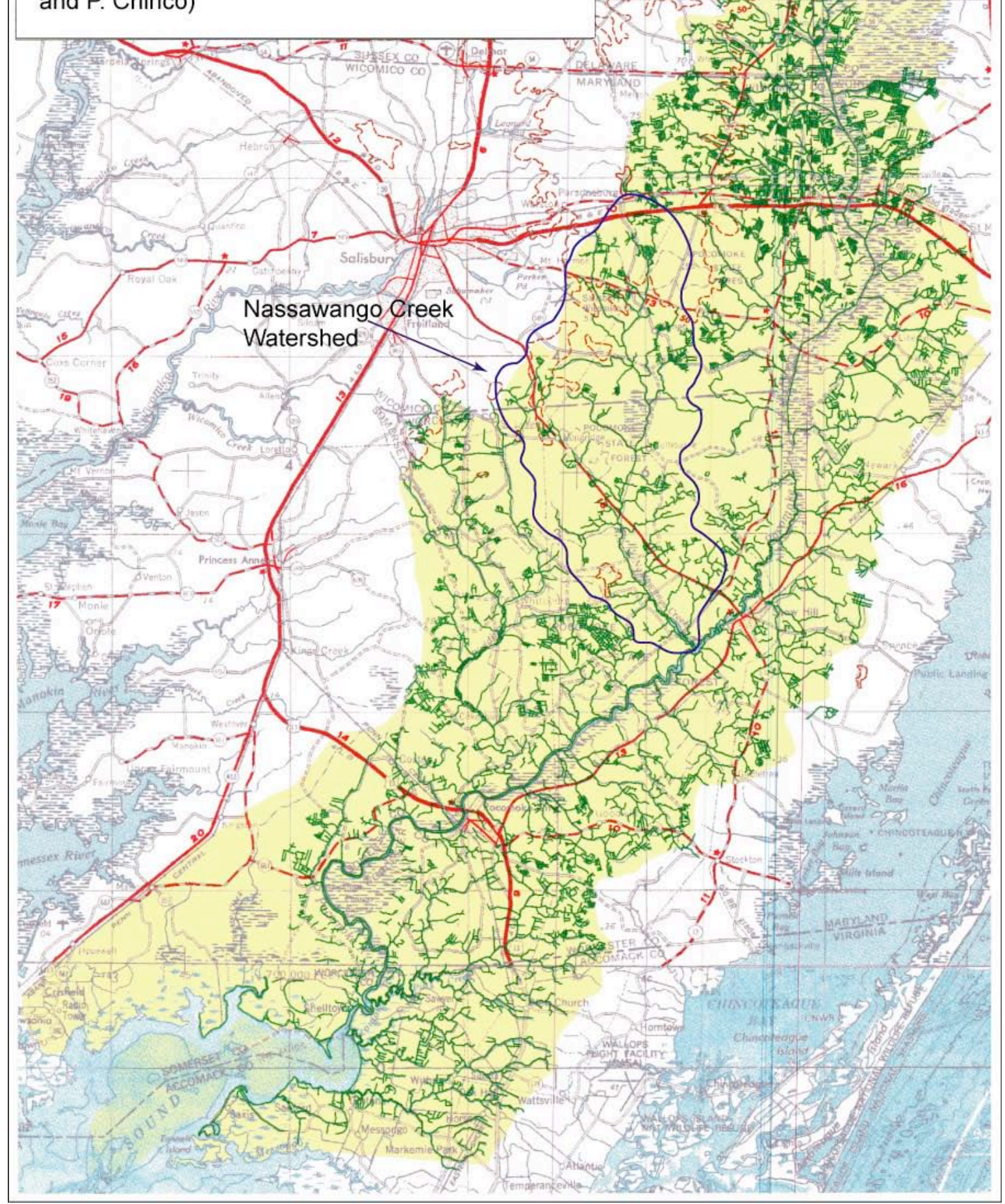

Figure 4. Ditching of the Pocomoke River watershed (from Bricker and others, 2003.) 


\section{Geomorphic Features on Pleistocene and Holocene Transgressive Deposits in Littoral/ Back-Bay Environments of the Atlantic Coast Portion of Worcester County}

The eastern margin of Worcester County is dominated by coastal margin landforms including Assateague Island, and other barrier islands with shore facing littoral deposits, sand dunes, and fringing salt marshes along the margins of Chincoteague Bay and Assawoman Bay. A platform of low marine terraces (less than 2 meters above sea level) lies west of Ocean City, Maryland. The shape of the platform indicates subtle shore-face, parallel beach ridges or off-shore bars. An overprint pattern of the raised rim basin morphology described from the terrace surfaces of the Pocomoke valley is also visible, superimposed on the shore-face morphology. These surficial features are currently being either submerged or eroded as sea level rises. The raised rims are the last remnants.

A coastwise scarp trending NNE to SSW bounds the coastal lowlands to the east. West of Ocean City, the scarp is tangential with a beach ridge of the same orientation. The configuration of scarp and beach ridge topography west of Ocean City, extending to the south for 10 kilometers, attains elevations equal to the altitude of the Omar-Accomac terrace deposits, up to 10-12 meters. To the north, across Assawoman Bay, the scarp is prominent but an associated beach ridge is not. The terraces around the headwaters of the Indian River are in the same altitude range as the Kent Island Formation terraces in the Pocomoke valley. Southward, along the constant linear trend of beach ridges, the altitude of the beach ridge drops to a few meters; the underlying terrace deposits were designated the Sinepuxent Formation by Owens and Denny (1979). The beach ridge trend continues across minor embayments into Virginia where the tops of the beach ridge deposits are barely above sea level. Small re-entrant bays occur between the south trending beach ridges and the Omar-Accomack uplands that are eroded by numerous small ravines that have entrenched through the motifs of dune fields and surficial deposits of the raised rim, closed basins.

Within the north-central, east side of the Pocomoke Valley is a subtle linear ridge that is at about same elevation $(8-10 \mathrm{~m})$ as the higher beach ridge remnants on the Atlantic side of the divide. This narrow ridge ( $100-200 \mathrm{~m}$ wide) follows contours and mimics the extant of the terrace shore line; it is probably an ancient beach deposit of an earlier Pocomoke estuary. It is quasi-level and does not rise and fall across pre-existing topography in the manner of the dunes.

Within the Pocomoke valley, terraces of the Kent Island equivalents are a bit more distinct, and are inset below the barrier island bars, and back-bay terraces of the Omar Formation.

Holocene barrier islands including Assateague Island are characterized by numerous, storm-cut and filled inlets overprinted by dune fields; the older dune ridges are stabilized by forests. The slightly higher wetlands of the bayside fringing marshes may reflect the morphology of wash-over fans from coastal storms. 


\section{Ephemeral Anthropogenic Land-Use Overprints:}

Although the LIDAR based imagery has been processed to remove intermediate reflectors from the tree canopy, and other features (Johnson and others, 2006), it is still possible to distinguish the texture of the forest canopy, cleared fields, old abandoned fields, and certain types of row crops (corn) on the LIDAR-DEM image. Some nondescript linear features may in fact be piles and windrows of rotting stumps, roots, and tree toppings that remain from timbering and land clearing. Some sites may eventually prove to be sites of charcoaling works. Pivot irrigators, distinctive cultivation patterns, and some fences or hedge rows, may also be visible. Road fill and ramps, borrow pits, and land fills are also obvious. Drainage ditching is densely spaced on many different terrace elevations. There may be $50 \%$ more cumulative length of ditching than can be mapped from the $7 \frac{1 / 2}{}$ ' topography. (Figure 4). Extensively ditched fields indicate poor permeability of regolith on Miocene Pensauken upland surfaces or Pleistocene terraces underlain by bay-bottom mud.

The LIDAR signatures from dunes and the subtle relief of raised rims around basins indicate that despite 10 millennia of forest growth, and deforestation from insects, fires, hurricanes, farming and ditching, the surfaces remain relatively un-modified. The preservation of low relief details supports other evidence (Bricker, et al, 2003) that the Pocomoke River watershed has produced extremely small volumes of sediment for export to Pocomoke Sound and the Chesapeake Bay during the last 10,000 years.

\section{History of the Landscape Interpreted from Sequences of Cross Cutting Topographic Features (Substituting Space for Time)}

As previously described, the geomorphic signatures of various processes that have shaped the landscape can now be interpreted with high resolution provided by LIDAR based DEM maps at scales previously unattainable. Close inspection of the details, now commonly available, leads to a variation of sequence stratigraphy (known in some areas as the morphological sequence). Cross cutting relationships and the ordering of events in the deposition and destruction of sequences that include all the same basic deposits can now be juxtaposed against the cross-cutting relationships of depositional sequences of other processes. A time/space sequence can be interpreted from the resultant assemblages of morphological-sequences. Relative timing of changes in the dominance of earth surface processes can also be established. Such an interpretation of landscape evolution follows from the assemblages of different deposits and landforms. We are now on the threshold of interpreting landscape evolution from the cross-cutting relationships of deposits emplaced during transitional stages of sequencing geomorphic processes. This requires recognizing both erosional features/events, deposits/ events as a continuum of fluvial, eolian, and estuarine processes. 


\section{Last interglacial}

During the last sea level high stand above present sea level, (Stage 5e), The Pocomoke River was a shallow estuary that filled the valley, The sediments that accumulated in the valley are the Kent Island terrace deposits. The enclosing uplands of the watershed were weathered and eroded, producing a regolith of residual sediments and slope deposits. Pollen spectra from peat deposits in the Kent Island Formation nearby on the Delmarva Peninsula (Newell, unpublished data) indicate arboreal assemblages that reflect climate changes much like pollen trends in deposits from the Holocene environment (Willard and others, 2000). As the climate cooled, sea level fell from the Stage 5E high-stand ( $80 \mathrm{KA}$ ?), and the Pocomoke River and its tributaries entrenched through the antecedent deposits.

\section{Wisconsinan}

Eventually, the climate on the Delmarva Peninsula became too harsh to support mixed forests of the mid-Atlantic. Sparse vegetation and grasslands were a transition stage to cold, desert-like conditions as sand dunes accumulated from the old estuary and flood plaln deposits. The resulting dune fields of the Parsonsburg Sand and windblown dunes were actively migrating during the glacial maximum (Wisconsinan-30,000 13,000 ybp). Vegetation was minimal; sand was eroded from exposed Kent Island terraces and the regolith on the Pensauken Formation. During the period of active dunes, the river valley was aggraded with braided streams that provided sand for the dune fields blowing out to the east. Random, isolated channel and meander bend reaches (near present sea level) are evidence of this period of braided channel deposits.

\section{Late Wisconsinan, LGM}

Across Delmarva, extensive slope deposits and underlying regolith are disrupted by random deformational features including frost wedges and involutions in the surficial deposits. The slope deposits and deformations are no longer active and indicate that much of Delmarva had a more rigorous freeze-thaw periglacial climate like the New Jersey coastal plain (French and others, 2007, Newell and others, 2000, Newell and Wyckoff, 1992).Wind-blown deposits (Parsonsburg) commonly overly these features and are locally interdigitated with slope and fluvial deposits. Details of similar stratigraphy have been described by Newell, 2005. As interpreted by French and others, 2007, the persistent high winds and deep chilling of the New Jersey and Delmarva microclimate was the result of katabatic winds from the terminus of the continental ice at Long Island, N.Y.

The composite motifs of raised rimmed basins concentrated on the old terraces are best interpreted as ephemeral ponds that also occurred at end of Pleistocene. Such ponds were shallow and probably completely frozen. With onset of seasonal warming and increased precipitation, these ponds, commonly underlain by impermeable materials, either breached and drained, or filled with peat. Although the composite landscapes of these features look like modern thaw ponds on thick, continuous permafrost in the high 
arctic (Carson and Hussey, 1962; Murton, 1996, 2001; French, 2007) that interpretation is doubtful because climate was dry, and evidence of deep, extensive, permafrost of long duration has not yet been recognized on the floors of the ephemeral ponds.

\section{Early Holocene}

At the onset of a warmer, wetter local Delmarva climate, increased precipitation induced higher discharge, which in turn triggered vigorous down cutting of the Pocomoke and its tributaries through the braided channel deposits that had been nourished by the windblown sand from the west. The entrenched channel reaches of the Pocomoke valley truncated both the proximal margins of the dune fields east of the valley and the isolated wide meander bend remnants.

Tributary valleys originating in the uplands on both sides of the Pocomoke sharply cut the dune field motif and the composite motif of raised rim basins (ephemeral ponds); initiating incision of the stream system after the ephemeral ponds and dune fields had formed. Initial incision may have been triggered by both thaw water and increased seasonal precipitation. The incision preceded sea level rise and the entire peninsula was sub-aerial through the Younger Dryas.

\section{Middle Holocene}

During the transition from Late Pleistocene- to Early Holocene, entrenchment was rapid to local depths of at least 40 feet. Cores from the Pocomoke tidal wetlands near Shellpile have provided records of fluvial to marine Holocene fill as old as 7,000 ybp.

As the climate has warmed, dense arboreal vegetation has cut off mobile sand sheets except for limited areas cleared by fire and or agriculture.

Most of the flat terraces are poorly drained and forest is generally shallow rooted. Hurricanes and Northeasters occasionally lay down tracts of forest; the upturned roots would have produced mound and pit micro-relief. But no distinctive signature of this process has been identified on the LIDAR images. Tree-throw mounds and pits are common on the modern flood plain but are probably too small to dominate individual pixels in the digital images.

\section{Late Holocene}

As the Pocomoke valley becomes inundated from rising sea level, forestedwetland flood plain develops with abandoned meander channels, levees, and crevasse splays. The low gradient flood plain and low terraces are seasonally covered with standing water. Huge cypress swamps form near the northern limit of the species. Organic litter on the flood plain contributes to the slow release of surface water which is largely sediment free and functions as a "blackwater river system" (Kroes and others, 2007; Kroes and Hupp, in press).

Locally, in the Nassawango Creek, bog iron deposits form in modern sediments on the flood plain. The ferrous iron is derived from shallow groundwater moving through the back-bay terrace deposits of the Omar and Kent Island Formations. 
As sea level rises, the transition zone between salt tolerant and fresh water vegetation moves up the valley.

\section{Colonial to Modern land-use history}

The equilibrium landscape of forested wetlands and uplands was disturbed rapidly on a massive scale beginning with forest clear cutting and farming beginning in the $17^{\text {th }}$ century. New flood plain deposits are distinctive as veneers of fine sand derived from adjacent Parsonsburg deposits on the slopes. The new sediment covers old flood plain deposits, soils, and cut or burned stumps of cypress.

Bog iron continues to form in the new deposits on the flood plain. It has been mined locally, but deposits are still forming today. The shallow groundwater is charged with ferrous iron from sulfides in old bay sediments of the Kent Island and Omar Formations.

By the mid- $20^{\text {th }}$ century, the entire Pocomoke River watershed has been extensively ditched to drain fields for row crops that require heavy equipment.

Function of riparian wetlands for trapping sediment and nutrients is bypassed by the ditch system. Most of the modern sediment remains in the watershed because of low gradient and limited stream power for the transport of sand size particles. However, dissolved nutrients and nutrients sorbed on clay size particles and organic debris escape to enrich the waters of the Chesapeake Bay.

\section{SUMMARY}

Worcester County, Maryland includes an upland plateau of the central Delmarva Peninsula, almost the entire drainage system of the Pocomoke River, and short reaches of Atlantic Coast streams draining to Chincoteague and Assawoman Bays which are bounded on the ocean side largely by Assateague Island.

A new LIDAR based DEM map (Plate I, II), produced for flood prone area studies, reveals topographic details at such high resolution that the Pleistocene-Holocene geomorphic history can be interpreted to show the impact of climate change on the landscape during the transition from a cold arid climate to a warm, humid climate.

The topographic motifs that can be parsed from the map include extensive, thick fields of sand dunes, raised-rim, closed basin ephemeral lake beds, braided and meandering river reaches, coastal marshes, and littoral strands and paleo-inlets. Most of these landforms are either dormant today or out of scale with the efficacy of modern geomorphic processes.

Cross cutting relationships facilitate the interpretation of a relative stratigraphy of deposits and events. Much younger artifacts of land use and changing forest cover also overprint but do not obscure the details.

A brief history of climate change includes the antecedent last interglacial represented by estuarine and marine terraces, followed by deep incision of the drainage system during the lowering of sea level as the climate cooled and the continental ice accumulated. Persistent katabatic winds from the north overwhelmed the region with thick, extensive dunes and fields of wind blown sand. The domains of ephemeral ponds are commonly perched on terrace surfaces which may have been impermeable. Shallow 
water trapped in these ponds was seasonally frozen and alternatively thawed. The traces of the ponds indicate a long history of pond formation and drainage interspersed with sediments from the dune fields. The entrenched valleys were largely filled with wind blown sediment and some slope deposits. The limited discharge of the streams flowed across the sandy flood plains as braided river systems. As the climate warmed and precipitation increased, vegetation locked the dune fields in place, the streams entrenched through the valley fill sediments. Currently, rising sea level has been systematically flooding the entrenched valleys. This complex system has functioned during the last several (7) millennia to store more sediment than it exports down stream to the larger Chesapeake.

Although sedimentary horizons from early land use are distinctive, the low relief landscape of Worcester County has not been a consistent sediment producer.

The very presence of the low relief signature of the rimmed basins (ephemeral ponds), and individual sand sheets of dune fields indicates that the Pocomoke Watershed has been stable for more than 10,000 years; surface erosion and modification by biological processes (tree throw or burrowing) has been extremely limited. The export of sediment is and has been nil (Kroes and others 2007; Kroes and Hupp, in press: Hupp, 2000; Gellis and others, 2006; Gellis and others, in press; Langland and Cronin, 2003). Sediment that has been eroded from fields is largely stored on the flood plains, or may even represent fine sand blown from cultivated fields and dumped into the swamps and flood plains.

The analysis of this map shows that cross cutting relationships can be used to establish a relative stratigraphy of events and deposits. The physiography of Worcester County is typical of much of Delmarva. And the map can be used to select several detailed areas for detailed studies of processes, age relationships, and rates. Actual ages can be determined with OSL dates and ${ }^{14} \mathrm{C}$ dates. Furthermore, dated sequences of pollen assemblages can now be compared to the continuous records from Holocene sediment fill from the Chesapeake (Willard and Korejwo, 2000). The map offers opportunities for coring, trenching, and Ground Penetrating Radar surveys of the internal details of the cold climate surficial deposits including spatial and textural parameters of dune fields, structures underlying the fields of ephemeral ponds, and proxies for approximating parameters of the paleoclimate during their production. 


\section{References cited}

Bricker, O.P., Newell, W.L., Simons, N., and Clark, I, 2003, Bog Iron ore in Nassawango Creek, Maryland, USGS Open File Report, OF03-346.

Carson, C.E. and Hussey, K.M., 1962, The oriented lakes of Arctic Alaska, Journal of Geology, v. 70, pp417-439.

Chandler, J.L., 1984, Topographic Map of Worcester County, Maryland Geological Survey.

Denny, C.S., and Owens, J.P., 1979, Sand Dunes on the Central Delmarva Peninsula, Maryland and Delaware: USGS Prof. Pap. 1067-C, 15 p.

Denny, C.S., and others, (1979) The Parsonsburg Sand in the Central Delmarva Peninsula, Maryland and Delaware: USGS Prof. Pap. 1067-B, 16p.

Demas, G.P., Burns, J.L., and Hall, R.L., 2004, Soil Survey of Worcester County, Maryland, U..S. Department of Agriculture, 203p.

Dyke, A.S., Andrews, T.T., Clark, P.U., England, J.H., Miller, G.H., Shaw, J. and Veillette, J.J., 2002, The Laurentide and Innuitian ice sheets during the last Glacial Maximum, Quaternary Science Reviews, vol. 21, pp 9-31.

French, H. M., 2007, The Periglacial Environment, Third Edition, John Wiley and Sons, Ltd, 458p.

French, H.M., Demitroff, M., and Forman, S.L., 2003, Evidence for Late- Pleistocene permafrost in the New Jersey Pine Barrens (Latitude $39^{\circ} \mathrm{N}$ ), Eastern USA, Permafrost and Periglacial Processes v. 14, pp 259-274.

French, H.M., Demitroff, M., and Forman, S.L., 2005, Evidence for Late- Pleistocene thermokarst in the New Jersey Pine Barrens (Latitude $39^{\circ} \mathrm{N}$ ), Eastern USA, Permafrost and Periglacial Processes v. 16, pp 173-186.

French, H.M., Demitroff, M., Forman, L.L., and Newell, W.L., 2007, A Chronology of Late-Pleistocene Permafrost Events in Southern New Jersey, Eastern USA, Permafrost and Periglacial Processes, v. 18, pp. 49-50.

Gellis, A.C., Hupp, C.R, Pavich, M.J., Landwehr, J.M., Banks, W.S.L., Hubbard, B., Ritchie, J.R., In Press, Sources, transport, and storage of sediment in the Chesapeake Bay watershed: U.S. Geological Survey Scientific Investigations Report.

Gellis, A.C., Banks, W.S.L., Langland, M.J., and Martucci, S., 2005, Suspendedsediment Data for Streams Draining the Chesapeake Bay Watershed, Water Years 
1952-2002: Scientific Investigations Report 2004-5056, 59 p.

Hall, R.L., 1973, Soil Survey of Worcester County, Maryland, U.S. Department of Agriculture, 78p.

Hupp, C.R. 2000, Hydrology, geomorphology, and vegetation of Coastal Plain rivers in the southeastern USA: Hydrological Processes, v. 14, p. 2,991-3,010.

Johnson, Z., Barlow R., Clark, I., Larsen, C., Miller, K. 2006, Worcester County Sea Level Inundation Model. Technical Report. Maryland Department of Natural Resources Publication 14-982006-166. 15p.

Jordan, R.R., 1964, Columbia (Pleistocene) deposits of Delaware: Delaware Geological Survey Bulletin No. 12, 69p.

Kroes, D.E., Hupp,C.R., and Noe, G.B., 2007, Sediment, nutrient, and vegetation trends along the tidal, forested Pocomoke River, Maryland, Chapter 5 in Conner, W.H., Doyle, T.W., and Krauss, K.W., (eds.) Ecology of Freshwater Swamps of Southeastern U.S., Springer.

Kroes, D.E., and Hupp, C.R., in press, Patterns of riparian sedimentation and subsidence along channelized and unchannelized reaches of the Pocomoke River, Maryland, Hydrologic Processes.

Langland, M., and Cronin, T., 2003, A Summary Report of Sediment Processes in Chesapeake Bay and Watershed, U.S. Geological Survey Water-Resources Investigations Report 03-4123.

McGee, W.J., 1888, The geology of the head of the Chesapeake Bay: U.S. Geological Survey, Annual Report 7, pp. 537-646.

Mixon, R.B., 1985, Stratigraphic and geomorphic framework of uppermost Cenozoic deposits in the southern Delmarva Peninsula, Virginia and Maryland: USGS Prof. Pap. 1067- G, 53p.

Mixon, R.B., Szabo, B.J., and Owens, J.P., 1982, Uranium-series dating of mollusks and corals, and age of Pleistocene deposits, Chesapeake Bay area, Virginia and Maryland: USGS Prof, Pap. 1067-E, 18p.

Mixon, R.B., Berquist, C.R., Jr, Newell, W.L., and Johnson, G.H., 1989, Geologic Map and generalized cross sections of the Coastal Plain and adjacent parts of the Piedmont, Virginia, USGS Miscellaneous Investigations Series - Map I-2033, 3 sheets.

Murton, J.B., 1996, Thermokarst-lake-basin sediments, Tuktoyaktuk Coastlands, Western Arctic Canada, Sedimentology, v.43, 737-760. 
Murton, J.B., 2001, Thermokarst sediments and structures, Tuktoyaktuk Coastlands, western Arctic Canada, Global and Planetary Change, v. 28, 175-192.

Newell, Wayne L., and Wyckoff, John S., 1992, Paleohydrology of four watersheds in the southern New Jersey Coastal Plain, in Gohn, G.S., ed., Proceedings of the 1988 U.S. Geological Survey Workshop on the Geology and Geohydrology of the Atlantic Coastal Plain: U.S. Geological Survey Circular 1059. pp 23-28.

Newell, W.L., Powars, D.S., Owens, J.P., Stanford, S.D., and Stone, B.D., 2000, Surficial geologic map of central and southern New Jersey, USGS Miscellaneous Investigations Series, Map I-2540-D, 3 sheets, scale 1:100,000.

Newell, W.L., Bricker, O.P., and Robertson, M. S., 2005, Geologic Map of the Colonial Beach, South 7.5' Quadrangle, Virginia, U.S. Geological Survey Open File Report 2005-1025

Newell, W.L., 2005, Evidence of Cold Climate Slope Processes from the New Jersey Coastal Plain: Debris Flow Stratigraphy at Haines Corner, Camden County, New Jersey, U.S. Geological Survey, Open File Report 2005-1296 http:///pubs.usgs.gov/of/2005/1296/

Owens, J.P., and Denny, C. S., 1978, Geologic Map of Worcester County, Maryland. Maryland Geological Survey.

Owens, J.P., and Denny, C.S., 1979) Upper Cenozoic Deposits of the Central Delmarva Peninsula, Maryland and Delaware: USGS Prof. Pap. 1067-A, 28p.

Owens, J.P., and Denny. C.S., 1984, Geologic Map of Somerset County, Maryland Geological Survey, Baltimore, Maryland.

Perkins, S.P., and Bacon, S.R., 1924, Soil Survey of Worcester County, Maryland. U.S. Department of Agriculture, 31p.

Rasmussen, W.C., and Slaughter, T.H., 1955, The groundwater resources In: The water resources of Somerset, Wicomico, and Worcester Counties by Rasmussen, W.C., Slaughter, T.H, Meyer, R.R., Bennet, R.R., and Hulme, A.E., State of Maryland Department of Geology, Mines and Water Resources, Bulletin 16, pp 1-170.

Shackleton, N.J., 1977, The oxygen isotope record of the late Pleistocene. Philosophical Transactions, Royal Soc. Of London, B 280: pp 169-182.

Sirkin, L. A., Denny, C.S., and Rubin, M., 1977, Late Pleistocene environment of the central Delmarva Peninsula, Delaware and Maryland, Geol. Soc. America Bull., v. 88, pp139-142.

Vogt, P.R., Halka, J.P., Hagen, R.A., and Cronin, T., 2000, Geophysical Environment in Chesapeake Bay: Marion-Dufresne Sites MD99-2205, 2206, and 2208. pp. 18- 
31; in: Initial Report on IMAGES V Cruise of the Marion-Dufresne to the Chesapeake Bay June 20-22, 1999, U.S. Geological Survey Open-File Report 00-306, T.M. Cronin, ed.

Wehmiller, J. F., Simmons, K. R., Cheng, H., Edwards, R. L., Martin-McNaughton, J., York, L. L., Krantz, D. E., and Shen, C.-C., 2004, Uranium-series coral age from the US Atlantic Coastal Plain - the "80 ka problem" revisited. Quaternary International, 120, 3-14.

Willard, D.A., and Korejwo, D.A., 2000, Holocene palynology from MarionDufresne Cores MD99-2209 and 2207 from Chesapeake Bay: Impacts of Climate and Historic Land-use change, in Initial Report on IMAGES V Cruise of the Marion-Dufresne to the Chesapeake Bay June 20-22, 1999, Thomas M. Cronin, ed., U.S. Geological Survey Open-File Report 00-306, pp. 78-86. 